of the Health Office and of the Inalende Maternity Centre for all the valuable assistance they afforded us during these trials. We would also like to thank members of the University of Ibadan Health Service, the Abadina Village Council, the health visitors of the School of Nursing, the Department of Social and Preventive Medicine, and the Department of Paediatrics, University of Ibadan, for their help.

The vaccines were kindly provided by the Wellcome Research Laboratories, and we thank Dr. T. M. Pollock and Dr. A. P. Goffe for their help and advice in the planning of these trials.
REFERENCES

Collard, P., Hendrickse, R. G., Montefiore, D., Sherman, P., van der Wall, H. M., Morley, D., Goffe, A. P., Laurence, G. D., and Pollock, T. M. (1961). Brit. med. F., 2, 1246.

Gans, B., Macnamara, F. N., Morley, D., Thomson, S. W., and Watt, A. (1961). W. Afr. med. F., 10, 253.

Goffe, A. P., and Laurence, G. D. (1961). Brit. med. F., 2, 1244.

McGregor, I. A., Billewicz, W. Z., and Thomson, A. M. (1961). Ibid., 2, 1661.

Morley, D., Woodland, M., and Martin, W. J. (1963). F. Hyg. (Lond.), 61, 115 .

\title{
Sulthiame in Treatment of Epilepsy
}

\author{
HUGH GARLAND,* T.D., M.D., F.R.C.P. ; DAVID SUMNER,* M.B., B.SC., M.R.C.P.
}

To claim to have evaluated a new anticonvulsant on the basis of 54 patients treated for no longer than 18 months would be wholly false. This study is presented rather to draw attention to a drug which has received little notice in English medical literature and in particular to point out the hazards which may attend its use.

Sulthiame differs in structure from other anticonvulsants, being a sulphonamide with a closed-ring structure. Chemically it is $N$-(4'-sulphamoylphenyl)-butanesultam-(1-4) (tetrahydro-2-p-sulphamoyl-1, 2-thiazine 1, 1-dioxide), and has the structure :<smiles>NS(=O)(=O)c1ccc(N2CCCCS(=O)(=O)O2)cc1</smiles>

\section{Literature}

Pharmacological studies (Wirth et al., 1960) showed sulthiame to be highly effective in controlling electroconvulsive seizures in mice, having a far higher therapeutic index than phenobarbitone or diphenylhydantoin, although this difference was less marked in the control of attacks induced by leptazol ("metrazol"). Sulthiame is a weak carbonic anhydrase inhibitor and has a mild diuretic effect. It has a mild tranquillizing action in hamsters but no hypnotic effect. No evidence was found of gastric irritation nor of damage to the liver or central nervous system.

Following this work, a number of clinical reports have appeared initially from Germany but later from other countries. Fluegel et al. (1960) found the drug to be ineffective in minor epilepsy (petit mal), less effective than diphenylhydantoin in the control of major epilepsy (grand mal), but very effective in the control of temporal-lobe attacks. The only side-effects they noted were slight tiredness and lassitude, transitory paraesthesiae, dyspnoea, and occasional nausea. Skin reactions (unspecified) occurred in a few patients. The drug was given to 150 epileptics, in 84 of whom electroencephalograms had been performed; 31 of these showed focal patterns, 16 of which disappeared during sulthiame therapy.

Engelmeier (1960) treated 73 patients with sulthiame. Five proved to be intolerant, 28 were unaffected, and 40 were "improved." Of the five who were unable to tolerate the

* From the Department of Neurology, the General Infirmary at Leeds. drug, three were unable because of gastro-intestinal disturbances ("gastro-hepatic syndrome"), one because of oedema, and one because of dizziness and drowsiness. Other sideeffects were often seen, however, the commonest being paraesthesiae and milder gastro-intestinal disturbances.

Raffauf (1960) gave the drug to 81 epileptics with the following results : 60 (74\%) showed " marked improvement," $19(23 \%)$ were unchanged, and $2(3 \%)$ were worse. $\mathrm{He}$ gained the impression that the drug was most effective in the control of temporal-lobe attacks and claimed that side-effects were remarkably low, although in fact $25 \%$ complained of paraesthesiae and $10 \%$ of dyspnoea. One patient complained of angina of effort while taking sulthiame, and one had to stop the drug because she developed hypotension. Raffauf used a dose of $600 \mathrm{mg}$./day, combined with other anticonvulsants in $49(60 \%)$.

Haran (1962) treated 48 epileptics of long standing with sulthiame in a dose of $600 \mathrm{mg}$./day. In those patients who improved other anticonvulsants were withdrawn. Of the 40 who were followed up, 7 (17.5\%) were " much improved," 12 $(30 \%)$ were "improved," $20(50 \%)$ were unchanged, and 1 $(2.5 \%)$ became worse. Specific areas of improvement were found to be the reduction in irritability and aggression together with reduction in unmotivated violent or manic behaviour. The only side-effect noted was sleepiness in one patient.

Overvad (1962) reviewed 104 patients treated with sulthiame for from 5 to 15 months : $53(52 \%)$ remained free from attacks, but $10(19 \%)$ of these abandoned the drug because of side-effects or because it was ineffective. LaVeck et al. (1962) reported their experiences with 99 mentally retarded brain-damaged epileptics treated with sulthiame for six months : 32 remained fit-free for this period, but unlike previous authors they considered that toxicity was the limiting factor in the usefulness of the drug. Of the remainder 15 were " markedly improved" and 11 "improved." An average dose of $600 \mathrm{mg}$./day was used, but nevertheless lethargy, anorexia, or ataxia were found in 52 of their patients.

Ingram and Ratcliffe (1963), in a study of 37 children treated with sulthiame, found that $90 \%$ of those with hyperkinetic behaviour were improved or completely controlled, as were $80 \%$ of those with myoclonic jerks but only $45 \%$ of those with other forms of epilepsy; $22(60 \%)$ showed side-effects, the commonest being hyperventilation (57\%), drowsiness $(14 \%)$, nausea or vomiting $(11 \%)$, and paraesthesiae $(8 \%)$. Bray and Bower (1963) treated 22 children with refractory epilepsy with sulthiame, and while $8(36 \%)$ improved con- 
siderably, in $10(45 \%)$ the drug had to be discontinued. They noted that an initial response did not necessarily foreshadow prolonged improvement and they were not able to confirm Ingram and Ratcliffe's findings with respect to hyperkinetic behaviour or myoclonic jerks. Of the 10 who had to abandon the drug, eight did so because the attacks became more frequent and two because of respiratory disturbances. Davies and Leyshon (1963) added sulthiame to the other anticonvulsants in a group of mentally subnormal epileptics and stated that the results were good and that no side-effects were seen.

Liske and Forster (1963) added sulthiame in a dose of 600 mg./day to the previous anticonvulsant therapy in 53 chronic epileptics. They found a reduction in the frequency of attacks in 31 (58.5\%) patients, no change in 19 (35.8), while $3(5.7 \%)$ were made worse. More important, they stressed the liability of the drug to produce psychotic reactions, often of a paranoid nature, particularly in those who had suffered in the past from such episodes (4 $(7.5 \%)$ such reactions were seen in their series). Apart from this side-effect, drowsiness and confusion were seen in $9(17 \%)$ and paraesthesiae in $7(13 \%)$; there was one example each of ataxia, diplopia, and papilloedema. Shortness of breath occurred in $13(24.5 \%)$ patients.

\section{Material and Methods}

The 54 patients ( 35 men and 19 women) included in this trial were selected from those attending the neurological outpatient clinic of the General Infirmary at Leeds. The only criterion for selection was that they were severe epileptics who were resistant to conventional therapy. Their ages ranged from 16 to 61 years (mean 32.3), and the duration of their epilepsy was from 1 to 50 years (mean 18.6). Forty-

TABLE I.-Clinical Background of the 54 Patients in the Trial

\begin{tabular}{|c|c|c|c|c|c|c|}
\hline \multicolumn{2}{|c|}{ Type of Attack } & \multicolumn{3}{|c|}{ Aetiology } & \multicolumn{2}{|l|}{ E.E.G. Findings } \\
\hline 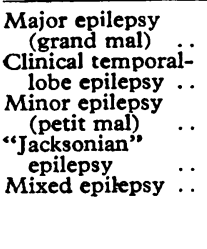 & $\begin{array}{r}19 \\
11 \\
1 \\
1 \\
22\end{array}$ & $\begin{array}{l}\text { "Idiopathic" } \\
\text { Birth trauma } \\
\text { Adult trauma } \\
\text { Sturge-Weber } \\
\text { syndrome } \\
\text { Oxycephaly } \\
\text { Toxoplasmosis } \\
\text { Cysticercosis }\end{array}$ & 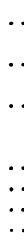 & $\begin{array}{r}37 \\
8 \\
5\end{array}$ & $\begin{array}{l}\text { Diffuse abnormality } \\
\text { Temporal-lobe } \\
\text { focus .. } \\
\text { Focus elsewhere .. } \\
\text { Subcortical and } \\
\text { "centrencephalic" } \\
\text { No abnormality .. }\end{array}$ & $\begin{array}{r}20 \\
17 \\
3\end{array}$ \\
\hline
\end{tabular}

three had been treated in the past with four or more drugs, the average number of drugs used in all the patients being 4.1. The types of epilepsy, aetiology, and E.E.G. findings are summarized in Table $I$.

Initially sulthiame was added to the patient's previous anticonvulsant treatment as an out-patient, but as soon as it was realized that the incidence of side-effects was so high each patient was admitted to hospital wherever possible for the period of stabilization. Forty-five patients were given sulthiame in a dose of $600 \mathrm{mg}$./day, six were given $800 \mathrm{mg}$./ day, and three were given $400 \mathrm{mg}$./day.

\section{Results}

Of the 54 patients who entered the trial 28 were unable to continue because of side-effects and four because their attacks became worse. Those who continued were followed up for periods ranging from 6 to 18 months (mean followup 10 months).

The overall results are given in Table II, while Table III shows the results in those who were able to continue with the trial. There was no evidence that sex, age, the aetiology or duration of the epilepsy, the E.E.G. findings, the frequency of attacks, or previous drug intolerance had any effect either on the control of the attacks or on the incidence of sideeffects. The one factor which did seem to affect the result was the number of drugs with which any patient had been treated before. These findings are shown in Table IV and indicate that the response is significantly better in those patients who had had fewer drugs in the past. This can only

TABLE III.-Results in Those Followed Up for a Mean Period of 10

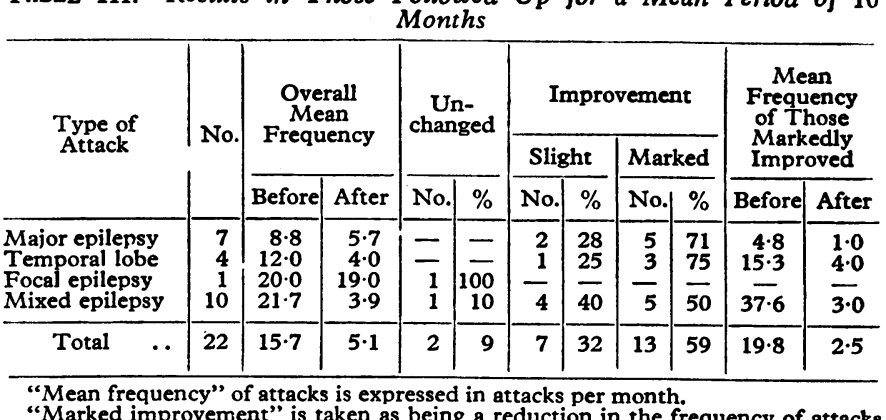
to less than half of that before taking the drug.

TABLE II.-Overall Results

\begin{tabular}{|c|c|c|c|c|c|c|c|c|c|c|c|c|c|c|c|c|}
\hline \multirow{2}{*}{\multicolumn{3}{|c|}{ Type of Attack }} & \multirow{3}{*}{ No. } & \multirow{3}{*}{$\begin{array}{l}\text { Mean } \\
\text { Frequency } \\
\text { Before } \\
\text { Sulthiame }\end{array}$} & \multirow{2}{*}{\multicolumn{2}{|c|}{ Worse }} & \multirow{2}{*}{\multicolumn{2}{|c|}{ Unchanged }} & \multicolumn{4}{|c|}{ Improvement } & \multirow{2}{*}{\multicolumn{2}{|c|}{ Intolerant }} & \multirow{2}{*}{\multicolumn{2}{|c|}{$\begin{array}{l}\text { Mean Frequency } \\
\text { of Those } \\
\text { Markedly Improved }\end{array}$}} \\
\hline & & & & & & & & & \multicolumn{2}{|c|}{ Slight } & \multicolumn{2}{|c|}{ Marked } & & & & \\
\hline & & & & & No. & $\%$ & No. & $\%$ & No. & $\%$ & No. & $\%$ & No. & $\%$ & Before & After \\
\hline $\begin{array}{l}\text { Major epilepsy } \\
\text { Temporal lobe } \\
\text { Minor epilepsy } \\
\text { Focal epilepsy } \\
\text { Mixed epilepsy }\end{array}$ & $\begin{array}{l}\ldots \\
\cdots \\
\cdots \\
\cdots\end{array}$ & $\begin{array}{l}\ldots \\
\because \\
\cdots\end{array}$ & $\begin{array}{r}19 \\
11 \\
1 \\
1 \\
22\end{array}$ & $\begin{array}{r}9 \cdot 7 \\
9 \cdot 9 \\
12 \cdot 0 \\
20 \cdot 0 \\
26 \cdot 9 \\
\end{array}$ & $\begin{array}{l}3 \\
3 \\
1 \\
3 \\
\end{array}$ & $\begin{array}{r}16 \\
27 \\
100 \\
14\end{array}$ & $\begin{array}{l}6 \\
3 \\
1 \\
4\end{array}$ & $\begin{array}{r}32 \\
27 \\
100 \\
18\end{array}$ & $\frac{2}{\frac{2}{6}}$ & $\begin{array}{l}10 \\
\frac{18}{27}\end{array}$ & $\begin{array}{l}8 \\
3 \\
9\end{array}$ & $\begin{array}{l}42 \\
\frac{27}{41}\end{array}$ & $\begin{array}{r}13 \\
\frac{6}{9}\end{array}$ & $\begin{array}{l}68 \\
\frac{54}{41}\end{array}$ & $\begin{array}{l}8 \cdot 0 \\
15 \cdot 3 \\
\frac{45 \cdot 8}{4}\end{array}$ & $\begin{array}{l}1.05 \\
0.66 \\
5.0\end{array}$ \\
\hline Total & .. & .. & 54 & $17 \cdot 0$ & 10 & 18 & 14 & 26 & 10 & 19 & 20 & 37 & 28 & 52 & 35.9 & $4 \cdot 3$ \\
\hline
\end{tabular}

TABLE IV.-Relation of Response to Previous Therapy

\begin{tabular}{|c|c|c|c|c|c|c|c|c|c|c|c|c|c|c|c|c|c|}
\hline \multirow{3}{*}{\multicolumn{3}{|c|}{ Previous Therapy }} & & \multirow{3}{*}{ No. } & \multirow{3}{*}{$\begin{array}{c}\text { Mean } \\
\text { Frequency } \\
\text { Before } \\
\text { Sulthiame }\end{array}$} & \multirow{2}{*}{\multicolumn{2}{|c|}{ Worse }} & \multirow{2}{*}{\multicolumn{2}{|c|}{ Unchanged }} & \multicolumn{4}{|c|}{ Improvement } & \multirow{2}{*}{\multicolumn{2}{|c|}{ Intolerant }} & \multirow{2}{*}{\multicolumn{2}{|c|}{$\begin{array}{c}\text { Mean Frequency } \\
\text { of Those } \\
\text { Markedly Improved }\end{array}$}} \\
\hline & & & & & & & & & & \multicolumn{2}{|c|}{ Slight } & \multicolumn{2}{|c|}{ Marked } & & & & \\
\hline & & & & & & No. & $\%$ & No. & $\%$ & No. & $\%$ & No. & $\%$ & No. & $\%$ & Before & After \\
\hline $\begin{array}{l}3 \text { drugs or } \\
4 \text { drugs or } \\
\end{array}$ & & .. & $\therefore$ & $\begin{array}{l}14 \\
40 \\
\end{array}$ & $\begin{array}{l}10 \cdot 4 \\
21 \cdot 3 \\
\end{array}$ & $\overline{10}$ & 25 & $\begin{array}{r}2 \\
12 \\
\end{array}$ & $\begin{array}{l}14 \\
30 \\
\end{array}$ & 1 & $\begin{array}{c}7 \\
22 \cdot 5 \\
\end{array}$ & $\begin{array}{r}11 \\
9 \\
\end{array}$ & $\begin{array}{ll}79 \\
22.5\end{array}$ & $\begin{array}{r}6 \\
22 \\
\end{array}$ & $\begin{array}{l}45 \\
55\end{array}$ & $\begin{array}{l}12 \cdot 0 \\
43 \cdot 4\end{array}$ & $\begin{array}{l}1 \cdot 8 \\
5 \cdot 2\end{array}$ \\
\hline Total & $\cdots$ & $\therefore$ & $\cdots$ & 54 & $17 \cdot 0$ & 10 & $18 \cdot 5$ & 14 & 26 & 10 & $18 \cdot 5$ & 20 & 37 & 28 & 52 & $35 \cdot 9$ & $4 \cdot 3$ \\
\hline
\end{tabular}

"The difference between these two figures is highly significant $(P<0.01)$.

"Marked improvement" is taken as being a reduction in the frequency of attacks to less than half of that before taking the drug. 
mean that these individuals are presumably less resistant to anticonvulsant therapy than the bulk of those in the trial who represent the "hard core" of uncontrolled drug-resistant epileptics.

Transitory side-effects were seen in 10 patients and sideeffects of sufficient severity to lead to withdrawal of the drug occurred in 28. The nature of these side-effects and their frequency are shown in Table $\mathrm{V}$. No evidence of liver damage or of any blood dyscrasia was found.

TABLE V.-Frequency of the Occurrence of Various Side-effects

\begin{tabular}{|c|c|c|c|c|c|c|c|c|}
\hline \multicolumn{3}{|c|}{$\begin{array}{l}\text { Transitory } \\
\text { Side-effects }\end{array}$} & \multicolumn{6}{|c|}{ Severe and Prolonged Side-effects } \\
\hline 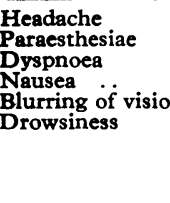 & $\begin{array}{l}\because \\
\because \\
\ddot{n} \\
\cdots\end{array}$ & $\begin{array}{l}3 \\
3 \\
2 \\
2 \\
2 \\
1\end{array}$ & $\begin{array}{l}\text { Ataxia . . } \\
\text { Drowsiness } \\
\text { Confusion } \\
\text { Headache } \\
\text { Psychotic re } \\
\text { (schizophre } \\
\text { psychosis 2; } \\
\text { depression } \\
\text { Vertigo .. }\end{array}$ & $\begin{array}{l}. \\
\therefore \\
\therefore \\
\text { tions } \\
\text { orm } \\
\text { rious } \\
\ldots\end{array}$ & $\begin{array}{r}14 \\
9 \\
9 \\
8 \\
6\end{array}$ & $\begin{array}{l}\text { Dysarthria } \\
\text { Blurring of v } \\
\text { Nausea or vo } \\
\text { Insomnia .. } \\
\text { Dyspnoea . } \\
\text { Paraesthesiae } \\
\text { Papular rash } \\
\text { Ptosis .. }\end{array}$ & $\begin{array}{l}\cdots \\
\text { ing } \\
\cdots \\
\cdots \\
\cdots \\
\cdots\end{array}$ & $\begin{array}{l}5 \\
4 \\
3 \\
3 \\
2 \\
2 \\
1 \\
1\end{array}$ \\
\hline
\end{tabular}

Unlike the psychotic episodes seen by Liske and Forster (1963), those occurring in this series did so against a normal background in all but one patient who had had a vaguely paranoid approach to life for some years. Of the side-effects which appeared, nine did so within 24 hours, seven in two days, seven within a week, two in two weeks, one in three weeks, and two in one month.

\section{Conclusions}

Very different results have been obtained by various workers from the administration of sulthiame, and in an awareness of frequent and serious side-effects our results are much more in keeping with the findings of LaVeck et al. (1962) and Liske and Forster (1963) in America than with those of the original German workers. There seems no doubt that sulthiame can exert a powerful anticonvulsant action, but its usefulness is limited by widespread and often alarming and serious side-effects. On this basis we feel that it is safer to admit patients to hospital for stabilization with the drug, although as the bulk of the side-effects appear within a week this need not be for a long period.

\section{Summary}

Sulthiame has been used in the treatment of 54 severe cases of epilepsy not controlled by other drugs. It had a valuable anticonvulsant action in 20 of these patients.

Severe side-effects were seen in 28 of the patients taking the drug.

In spite of these side-effects sulthiame is of value in the most-resistant epileptics.

Because of its side-effects, under no circumstances should sulthiame be used as the first drug in the treatment of any form of epilepsy.

We wish to thank Messrs. F.B.A. Pharmaceuticals, Limited, who supplied the sulthiame ("ospolot") which was used in this trial.

\section{REFERENCES}

Bray, C. A. R., and Bower, B. D. (1963). Develop. Med. Child Neurol.,

Davies, T. S., and Leyshon, M. W. (1963). Lancet, 2, 939.

Engelmeier, M. P. (1960). Dtsch. med. Wschr., 85, 2207.

Fluegel, F., Bente, D., and Itil, T. (1960). Ibid., 85, 2199

Haran, T. (1962). Irish F. med. Sci., pp. 441, 427.

Ingram, T. T. S., and Ratcliffe, S. G. (1963). Develop. Med. Child Neurol., 5, 313.

LaVeck, G. D., de la Cruz, F., and Thomas, D. B. (1962). Neurology (Minneap.), 12, 923.

Liske, E., and Forster, F. M. (1963). 7. New Drugs, 3, 32.

Overvad, E. (1962). Ugeskr. Lag., 124, 1400.

Raffauf, H. J. (1960). Dtsch. med. W wchr., 85, 2203. Wirth, W., Hoffmeister, F., Friebel, H., and Sommer, S. (1960). Ibid.,
85, 2195 .
In three years before the use of external massage six cases of circulatory arrest were treated and the same number of cases were seen in the subsequent six months. The larger number of cases seen latterly is due to my interest in the problem and not to an increase in incidence of the condition. Acid-base measurements were obtained in five of the last six cases, and four were treated with sodium bicarbonate solution. The clinical features in all 12 cases are given (Table I) and briefly summarized (Table II). The arrest occurred in the operating-theatre in eight cases; effective cardiac function was restored in seven cases, and in three of these the patients survived.

Acid-base Data.-Attention was directed to the importance of acidosis by Case 7, which has been previously reported (Stewart, Stewart, and Gillies, 1962). The acid-base data for four subsequent cases of circulatory arrest are shown (Table III). The absence of acidosis in one patient (Case 9) illustrates that it does not inevitably result from cardiac arrest. In this patient the arrest was noticed and was treated immediately, and * Lecturer in Surgery, University of St. Andrews, Queen's College,
Dundee. Present address: The Radcliffe Infirmary, Oxford. 